einstein

Official Publication of the Instituto Israelita

de Ensino e Pesquisa Albert Einstein

ISSN: 1679-4508 | e-ISSN: 2317-6385

\title{
Streptococcus mutans detection in saliva and colostrum samples
}

\author{
Detecção de Streptococcus mutans em amostras \\ de saliva e colostro
}

\author{
Camilla Beatriz da Silva', Marcelly Milhomem Mendes', Bárbara Rocha Rodrigues'1, \\ Thiago Lima Pereira', Denise Bertulucci Rocha Rodrigues' ${ }^{1}$ Virmondes Rodrigues Junior², \\ Virginia Paes Leme Ferriani ${ }^{3}$, Vinicius Rangel Geraldo-Martins ${ }^{1}$, Ruchele Dias Nogueira1,3 \\ Universidade de Uberaba, Uberaba, MG, Brazil. \\ 2 Universidade Federal Triângulo Mineiro, Uberaba, MG, Brazil. \\ ${ }^{3}$ Pós-Graduação em Saúde da Criança e do Adolescente, Faculdade de Medicina de Ribeirão Preto, Universidade de São \\ Paulo, Ribeirão Preto, SP, Brazil.
}

DOI: 10.31744/einstein_journal/2019A04515

\section{ABSTRACT}

Objective: To detect Streptococcus mutans in colostrum and saliva of neonates and compare with its detection in saliva of mothers. Methods: Forty-three healthy women, full-term gestations with no complications, submitted to elective Cesarean section, and their newborns were included in the study. Samples were investigated by polymerase chain reaction to detect $S$. mutans in genetic material from the samples. Results: Approximately $16 \%$ of colostrum samples showed $S$. mutans, but not correlated with the presence of the bacteria in both samples of saliva. $S$. mutans was detected in 49 and $30 \%$ of saliva samples of mothers and neonates, respectively. There was a positive correlation in $S$. mutans detection between types of saliva. The number of maternal samples of saliva with detectable $S$. mutans was smaller in women receiving dental treatment during pregnancy. Tooth brushing, three times a day, influenced the detection of $S$. mutans in both the saliva and the colostrum. Conclusion: Although maternal saliva may present $S$. mutans, few samples of colostrum present the bacteria. The presence of bacteria in neonate saliva may be related to contact before birth. Dental treatment and hygiene habits seem to influence the detection of $S$. mutans in samples of maternal saliva and colostrum.

How to cite this article:

Silva CB, Mendes MM, Rodrigues BR, Pereira

$T L$, Rodrigues DB, Rodrigues Junior V, et al.

Streptococcus mutans detection in saliva

and colostrum samples. einstein (São Paulo).

2019;17(1):eA04515. http://dx.doi.org/

10.31744/einstein journal/2019A04515

Corresponding author:

Ruchele Dias Nogueira

Avenida Nenê Sabino, 1,801 - Universitário

Zip code: 38055-500 - Uberaba, MG, Brazil

Phone: (55 34) 3319-8800

E-mail: ruchele_nogueira@yahoo.com.br

Received on:

Apr 5, 2018

\section{Accepted on:}

Aug 17, 2018

Conflict of interest:

none.

Copyright 2019

\section{(c) By}

This content is licensed

under a Creative Commons

Attribution 4.0 International License.

\section{Keywords: Streptococcus mutans; Saliva; Colostrum}

\section{RESUMO}

Objetivo: Detectar Streptococcus mutans no colostro e na saliva de recém-nascido, e comparar com a detecção na saliva da mãe. Métodos: Foram incluídos no estudo 43 mulheres saudáveis, com gestações a termo e sem complicações, que tiveram cesariana eletiva, e seus recémnascidos. As amostras foram investigadas por reação de polimerase em cadeia para a detecção de S. mutans em material genético extraído das amostras. Resultados: Cerca de $16 \%$ das amostras de colostro apresentaram $S$. mutans, não sem correlação com a presença das bactérias em ambas amostras de saliva. S. mutans foi detectado em 49 e $30 \%$ das amostras de saliva das mães e recém-nascidos, respectivamente. Houve correlação positiva na detecção de $S$. mutans entre os tipos de saliva. 0 número de amostras de saliva materna com $S$. mutans detectável foi menor nas mulheres que receberam tratamento odontológico durante a gravidez. A escovação três vezes ao dia influenciou na detecção do $S$. mutans tanto no saliva quanto no colostro. Conclusão: Embora a saliva materna possa apresentar $S$. mutans, poucas amostras de colostro apresentam a bactéria. A presença de bactéria na saliva de neonatos pode estar relacionada ao contato antes do nascimento. 0 tratamento odontológico e os hábitos de higiene parecem influenciar na detecção de $S$. mutans em amostras de saliva e colostro maternos.

Descritores: Streptococcus mutans; Saliva; Colostro 


\section{INTRODUCTION}

The genus Streptococci represents the majority of bacteria colonizing the oral cavity in the first months of life. ${ }^{(1)}$ The initial colonization of Streptococcus mutans occurs mainly after tooth eruption and is associated to the development of caries. Streptococci mutans colonize the dental surface, accumulate in the biofilm and produce acids that promote demineralization the tooth enamel. ${ }^{(2)}$ Dental caries is an infectious disease and a public health problem, especially in Brazil, because children are early colonized by $S$. mutans, even before tooth eruption. ${ }^{(3)}$ The early colonization can be associated with high consumption of sucrose, contact with highly infected individuals, ${ }^{(4-6)}$ and immaturity of mucosal immune system in children. ${ }^{(7,8)}$

The initial acquisition and establishment of the oral microorganisms occur by a microbial succession dependent on habits, contact with people and feeding. Breastfeeding is a common practice in Brazil, and it is necessary to investigate the colostrum components. It is known that colostrum has great bacterial diversity ${ }^{(9)}$ including Streptococci, Staphylococci, lactic acid bacteria and bifidobacteria, ${ }^{(10)}$ which can determine the body colonization of breastfed children. Intestinal microbiota of breastfed child is rapidly dominated by bifidobacteria ${ }^{(11,12)}$ and later, after dietary supplementation, is predominantly colonized by Enterobacteriaceae, Streptococcus, Bacteroides and Clostridium. ${ }^{(11)}$

Colostrum has several properties that benefit newborns, since it is an important source of nutritional and immunological components. ${ }^{(13,14)}$ The benefits of breast milk for numerous respiratory and intestinal infections have been amply described; however, for caries, they are unclear and controversial. There is evidence that dental caries is the negative outcome associated with breastfeeding, due to increased tooth decay in longer periods of breastfeeding. ${ }^{(15,16)}$ On the other hand, shorter duration of breastfeeding is suggested to be associated with increased risk for early childhood caries. ${ }^{(17)}$

Previous studies about the immunological analysis of colostrum from Brazilian women showed high levels of immunoglobulin A against $S$. mutans and its virulence antigens, which could contribute to the modulation of $S$. mutans infection. ${ }^{(18,19)}$ However, there is little information about the contribution of colostrum in the composition of oral colonization.

\section{OBJECTIVE}

To evaluate the presence of Streptococcus mutans in colostrum samples and compare with saliva samples from mothers and newborns, associating the findings with data of oral health.

\section{METHODS}

This study is an observational study with healthy neonates and mothers, who gave consent to take part. The Ethical Committee of the Faculdade de Medicina de Ribeirão Preto of Universidade de São Paulo approved this study under, CAAE: 02166713.4.0000.5145. Voluntary multiparous women were included in the study, submitted to clinical dental examination, and presented good oral (no caries or periodontal disease) and systemic health. They underwent elective Cesarean section in full-term gestation. Children with congenital malformations, perinatal hypoxia, intracranial hemorrhage, with length or weight incompatible with gestational age, or under antibiotic therapy were excluded from this study. Information on past medical/surgical and gestational history and oral hygiene was obtained through interviews with the mothers. Oral and maternal hygiene instructions were performed after the collections. All voluntaries (mothers and neonates) were referred for follow-up at the Dentistry Clinic of the University. Forty-three eligible samples came from a collection of 203 pregnant women who delivered at the maternity of Hospital das Clinicas of Faculdade de Medicina de Ribeirão Preto, who underwent oral cavity examination.

\section{Sample collection}

On the first day of hospitalization, the pregnant women were interviewed, submitted to oral cavity examination, and non-stimulated saliva collection. Saliva of neonates was collected shortly after birth and prior to any contact with the mother, including the first breastfeeding, to avoid contamination with nonsalivary components. Saliva samples were collected using sterile polypropylene transfer pipettes. A 250mM EDTA solution, pH 5.2 (Sigma, St Louis, MO, USA) was added to each sample prior to transport on ice to the laboratory, where they were stored at $-80^{\circ} \mathrm{C}$ until analysis.

Samples of colostrum were collected by manual expression into sterile polypropylene Falcon tubes, on the first day of lactation. After collection, the samples were transported on ice to the laboratory, centrifuged at $1,300 \mathrm{~g}$, for 5 minutes, and stored at $-80^{\circ} \mathrm{C}$ until the laboratorial procedures.

\section{Detection of Streptococcus mutans in samples}

DNA was extracted with the PowerLyzer PowerSoil DNA Isolation Kit (MO-BIO, Carlsbad, CA, USA) 
according to the manufacturer's instructions. Firstly, the samples were incubated with $20 \mathrm{mg} / \mathrm{mL}^{-1}$ lysozyme (Sigma, Tokyo, Japan) solution; containing $50 \mathrm{mM}$ Tris-HCl (pH 8.0) and 20mM EDTA, and incubated at $37^{\circ} \mathrm{C}$, for 30 minutes. Samples were immediately transferred to a $1.5 \mathrm{~mL}$ Eppendorf tube containing bead solution. After vortex mixing was carried out for 2 minutes to obtain bacterial suspension, which was transferred to a PowerLyzer Glass Bead Tube (MO-BIO, Carlsbad, CA, USA). The concentration of the purified PCR product was measured with a NanoDrop 2000 spectrophotometer (Thermo Scientific, Waltham, Massachusetts, USA). Sm479F/R primer pair (Sm479F: 5'-TCGCGAAAAAGATAAACAAACA-3'; and Sm479R: 5'-GCCCCTTCACAGTTGGTTAG-3')(20) was purchased from Invitrogen (Tokyo, Japan). The StepOne $^{\mathrm{TM}}$ Real-Time PCR System (Thermo Scientific, Waltham, Massachusetts, USA) performed Real-Time PCR. Each reaction tube contained reaction mixture, including 6.5 $\mu \mathrm{L}$ SYBR Green Master Mix (Roche, Illinois, EUA), $1 \mu \mathrm{L}$ of each primer, $4.5 \mu \mathrm{L}$ of ultrapure water, and $2 \mu \mathrm{L}$ of DNA extracted from samples. A total of 45 cycles of 15 seconds were performed at $94^{\circ} \mathrm{C}$ for denaturation; 30 seconds at $56^{\circ} \mathrm{C}$, for annealing; and 30 seconds at $72^{\circ} \mathrm{C}$, for extension followed by a melting

Table 1. Positive and negative samples of colostrum, maternal saliva, neonate saliva for detection of Streptococcus mutans

\begin{tabular}{lcc}
\hline Samples $\mathbf{n = 4 3}$ & Positive $\mathbf{n ~ ( \% )}$ & Negative $\mathbf{n ~ ( \% ) ~}$ \\
\hline Colostrum & $7(16)^{*}$ & $36(84)^{*}$ \\
Maternal saliva & $21(49)^{*}$ & $22(51)^{*}$ \\
Neonate saliva & $13(30)$ & $30(70)$ \\
\hline${ }^{2}$ test; $p<0.003 ; q=10.37$. & &
\end{tabular}

curve analysis of the PCR product. Two PCR tests were performed for all samples. Streptococci mutans (UA159) DNA was used as positive control.

\section{Statistical analysis}

The differences in the frequencies of detection of $S$. mutans in the samples were obtained by the $\chi^{2}$ test. The correlation between positive detection of $S$. mutans and data of interview were tested by Pearson's correlation coefficient. A p value $<0.05$ was considered statistically significant.

\section{RESULTS}

Streptococcus mutans was not detected in most samples of colostrum ( $84 \%)$, and of saliva of neonates $(70 \%)$ and of mothers $(51 \%)$ (Table 1$)$. The comparative analysis between the frequencies of positive and negative detection of $S$. mutans in the samples showed that there were statistically significant differences between colostrum and mothers' saliva, that is, maternal saliva presented more $S$. mutans than colostrum ( $\chi^{2}$ test; $\mathrm{p}<0.05)$. There was a positive correlation between positive and negative detection of $S$. mutans between baby and maternal saliva (Spearman correlation; $\mathrm{p}<0.05$; rs $=0.36$ ).

Most of the volunteers (70\%) did not undergo dental treatment during pregnancy (Table 2). Over $60 \%$ of women reported that regularly visited the dentist and brushed their teeth more than three times a day (Table 2). Although mothers who did not undergo dental treatment during pregnancy had detectable S. mutans (69\%), this difference was not statistically significant $(\mathrm{p}>0.05)$. The absence of dental treatment

Table 2. Samples with positive and negative detection of Streptococcus mutans in colostrum, maternal saliva, and neonate saliva, according to oral health

\begin{tabular}{|c|c|c|c|c|c|c|c|}
\hline \multirow[b]{2}{*}{ Data } & \multirow{2}{*}{$\begin{array}{c}n \\
(43)\end{array}$} & \multicolumn{2}{|c|}{ Colostrum } & \multicolumn{2}{|c|}{ Maternal saliva } & \multicolumn{2}{|c|}{ Neonate saliva } \\
\hline & & $\begin{array}{c}\text { Positive } \\
\text { n (\%) }\end{array}$ & $\begin{array}{c}\text { Negative } \\
\text { n (\%) }\end{array}$ & $\begin{array}{c}\text { Positive } \\
\text { n (\%) }\end{array}$ & $\begin{array}{c}\text { Negativa } \\
\text { n (\%) }\end{array}$ & $\begin{array}{c}\text { Positive } \\
\text { n (\%) }\end{array}$ & $\begin{array}{c}\text { Negative } \\
\text { n (\%) }\end{array}$ \\
\hline \multicolumn{8}{|l|}{ Oral health } \\
\hline Visits to the dentist frequently & 16 & $2(13)$ & $14(87)$ & $7(44)$ & $9(56)$ & $6(38)$ & $10(62)$ \\
\hline No & 27 & $5(19)^{*}$ & $22(81)^{*}$ & $14(52)^{*}$ & $13(48)^{*}$ & $7(26)$ & $20(74)$ \\
\hline \multicolumn{8}{|l|}{ Dental treatment during gestation } \\
\hline Yes & 13 & $3(23)$ & $10(77)$ & $4(31)$ & $9(69)$ & $5(38)$ & $8(62)$ \\
\hline No & 30 & $4(13)^{\dagger}$ & $26(87)^{+}$ & $17(57)^{\ddagger \ddagger}$ & $13(43)^{\ddagger \ddagger}$ & $8(27)^{\ddagger}$ & $22(73)^{\ddagger}$ \\
\hline \multicolumn{8}{|l|}{ Number of tooth brushing per day } \\
\hline $1-2$ & 16 & $4(25)^{\S}$ & $12(75)^{8}$ & $10(63)^{5}$ & $6(37)^{5}$ & $6(38)$ & $10(62)$ \\
\hline Over to 3 & 27 & $3(11)^{\uparrow}$ & $24(89)^{4}$ & $11(41)^{\pi}$ & $16(59)^{4}$ & $7(26)$ & $20(74)$ \\
\hline
\end{tabular}

* Fisher's exact test, $p<0.05 ;{ }^{\dagger}$ Fisher's exact test, $p=0.001 ;{ }^{\ddagger} \chi^{2}$ test, $p<0.001, q=18.47 ;{ }^{5}$ Fisher's exact test, $p<0.01 ;{ }^{\prime}$ Fisher's exact test, $p<0.01$ 
during gestation resulted in a higher number of positive samples in mothers' saliva than in colostrum and baby saliva $(\mathrm{p}<0.05)$.

There were no statistically significant differences in the frequency of $S$. mutans detection in the samples as per how many times mothers brush their teeth per day ( $p>0.05)$. There were also no statistically significant differences between colostrum and maternal and baby saliva $(p>0.05)$. There was a statistically significant difference in the frequency of $S$. mutans detection when compared between colostrum and maternal saliva, for both tooth brushing once-to-twice a day, and three times a day $(\mathrm{p}<0.01)$.

\section{DISCUSSION}

Analyze the presence of $S$. mutans by detection of genetic material in colostrum and saliva of mothers and newborns, as well as to compare the detection with data of oral health and hygiene habits. The Sm479F/R primer pair is highly specific and sensitive to identify $S$. mutans in either purified or mixed DNA samples. ${ }^{(20)}$ Although PCR was effective to detect $S$. mutans in samples and in the positive control, it must be considered that the genetic material detection using assays does not distinguish between living or non-living microorganisms, or bacterial fragments. All samples analyzed were from neonates born via Cesarean section, and the mode of delivery is a factor that influences the intestinal microbiota composition in early infancy. ${ }^{(21)}$

Although previous studies had detected species of Streptococcus abundantly in colostrum, ${ }^{(22)}$ in our study only $16 \%$ of the colostrum samples presented $S$. mutans. The entry pathways of bacteria through the mammary glands and exit via colostrum and mature milk are still unclear. There are some hypotheses about the presence of bacteria in the mammary glands, such as contact with the external environment, entry through other human body pathways, and a possible association of both hypotheses. ${ }^{(23)}$ External contamination can occur through contact of neonatal oral microbiota and skin microbiota during breastfeeding. ${ }^{(24)}$ This fact could explain the predominance of Staphylococcus and Streptococcus in breast milk, which are typical commensal of oral and skin microbiota. ${ }^{(25,26)}$ However, colostrum collection was performed before the first contact of the mother with the newborn, and after asepsis of breasts. Another pathway involves an internal bacterial route, which occurs when oral microorganisms reach the maternal intestine, leave by internalization in leukocytes (such as dendritic cells), migrate to the lymphatic vessels via blood circulation, and reach the mammary glands. ${ }^{(27,28)}$ Therefore, the minority of children received $S$. mutans via colostrum in the first day of life, but this process of bacterial translocation can be more intense, when the stimulus of suction and hormonal release stimulate better functioning of the mammary glands, and, consequently, secretion of bacteria that should be investigated.

The mouth is the site of the body with greater bacterial diversity as compared to vaginal or intestinal microbiota. ${ }^{(29)}$ As in other interfaces in our body, the oral mucosa is constantly fighting for tissue integrity. The immune system works to prevent the invasion of tissues by bacteria from the mouth. ${ }^{(30)}$ However, during gestation, there is an increased gingival permeability due to hormone changes, which can contribute to transfer of bacteria from the oral cavity to bloodstream. Some studies confirm presence of oral cavity bacteria in fetal tissues, especially those associated with periodontal disease, such as Fusobacterium nucleatum, in women who had preterm birth. ${ }^{(31)}$ Little is known about cariogenic bacteria from the maternal oral niche in immune development and fetal oral colonization.

The results shows that although the microorganism is present in some maternal saliva, it does not always enter the bloodstream, reaches the mammary glands, and is secreted in colostrum. Some mothers presented $S$. mutans in saliva but not in colostrum. And on contrary, the presence of $S$. mutans was observed in three samples of colostrum from mothers whose saliva had no $S$. mutans. Considering that $S$. mutans may be transient in the oral cavity, it is possible the bacteria were not present in the oral cavity upon collection. In general, $33 \%$ of infected women were able to transfer $S$. mutans through colostrum.

Of the newborns, $30 \%$ had $S$. mutans detectable in saliva, like their mothers. This suggests that exposure to bacteria and consequent colonization may occur in intrauterine life. S. mutans is transmitted to the fetus through the enteral-mammary via, reaching the oral cavity by swallowing the amniotic fluid. This mechanism could explain the immune stimulation and consequent production of specific salivary IgA against $S$. mutans in newborns, as found in previous studies. ${ }^{(7,8)}$ These findings differ from others that did not detect the bacteria at birth by the checkerboard technique, ${ }^{(8)}$ but only in children aged 5 to 11 months. ${ }^{(3)}$

The data obtained in the interviews with mothers provide important data regarding oral hygiene and behaviors, and their association with the presence of $S$. mutans in the samples. The mothers who stated not regularly visiting the dentist and not undergoing dental treatment during gestation presented higher detection 
of $S$. mutans in saliva. On the other hand, colostrum and baby saliva samples of these mothers had lower detection of $S$. mutans. The detection of $S$. mutans in patients brushing teeth more than three times a day was lower in all samples. The number of brushing times per day did not differ in positive or negative detection of $S$. mutans in each group of samples. The comparison between samples showed difference between colostrum and mother's saliva. There were more colostrum samples with negative detection than saliva samples, when considering tooth brushing one or twice a day, and more than three times a day.

\section{CONCLUSION}

Streptococcus mutans can be detected in a minority of colostrum samples. Behavioral data and hygiene habits appeared to influence the detection of Streptococci mutans in maternal saliva and colostrum samples. Dental treatment and caries prevention during pregnancy and after childbirth should be used to avoid the transmission of Streptococci mutans through maternal saliva and breast milk.

\section{ACKNOWLEDGMENTS}

This study was supported by Fundação de Apoio à Pesquisa de Minas Gerais (FAPEMIG) and Coordenação de Aperfeiçoamento de Pessoal de Nível Superior (CAPES) (2848/2011).

\section{CONTRIBUTION TO AUTHORSHIP}

Silva CB: collected data, performed the experiments and revised the manuscript. Mendes MM: designed the study, performed the experiments, collected and analyzed data and wrote the paper. Rodrigues BR: participated in the analysis and interpretation of data and revised the manuscript. Pereira TL: participated in the analysis and interpretation of data and revised the manuscript. Rodrigues DB: participated in the analysis and interpretation of data and revised the manuscript. Rodrigues Junior V: designed the study and revised the manuscript. Ferriani VP: designed the study and revised the manuscript. Geraldo-Martins VR: designed the study, supervised data collection and analysis and revised the manuscript. Nogueira RD: designed the study, supervised data collection and laboratorial experiments, participated in the interpretation of data and revised the paper.

\section{AUTHORS' INFORMATION}

Silva CB: http://orcid.org/0000-0002-1034-3790

Mendes MM: http://orcid.org/0000-0001-8800-8215

Rodrigues BR: http://orcid.org/0000-0003-3638-394X

Pereira TL: http://orcid.org/0000-0002-6601-0207

Rodrigues DB: http://orcid.org/0000-0003-0447-6244

Rodrigues Junior V: http://orcid.org/0000-0001-8706-4223

Ferriani VP: http://orcid.org/0000-0002-9555-9389

Geraldo-Martins VR: http://orcid.org/0000-0002-4312-3073

Nogueira RD: http://orcid.org/0000-0002-7706-1376

\section{REFERENCES}

1. Smith DJ, Taubman MA. Effect of local deposition of antigen on salivary immune responses and reaccumulation of mutans streptococci. J Clin Immunol. 1990; 10(5):273-81.

2. Heilmann A, Tsakos G, Watt RG. Oral Health Over the Life Course. In: BurtonJeangros C, Cullati S, Sacker A, Blane D, editors. A life course perspective on health trajectories and transitions [Internet]. Cham (CH): Springer; 2015 [cited 2018 Aug 17]. Chapter 3. Available from: http://www.ncbi.nlm.nih. gov/books/NBK385369/

3. Alves AC, Nogueira RD, Stipp RN, Pampolini F, Moraes AB, Gonçalves RB, et al. Prospective study of potential sources of Streptococcus mutans transmission in nursery school children. J Med Microbiol. 2009;58(Pt 4):476-81.

4. Berkowitz RJ. Causes, treatment and prevention of early childhood caries: a microbiologic perspective. J Can Dent Assoc. 2003;69(5):304-7.

5. Lynch DJ, Villhauer AL, Warren JJ, Marshall TA, Dawson DV, Blanchette $\mathrm{DR}$, et al. Genotypic characterization of initial acquisition of Streptococcus mutans in American Indian children. J Oral Microbiol. 2015;7(1):27182.

6. Maki Y, Sakayori T, Hirata S, Ishii T, Tachino A. Monitoring caries risks before the window of infection and later caries increment: a caries prediction study on rapid detection of Streptococcus mutans using monoclonal antibodies. Bull Tokyo Dent Coll. 2014;55(1):19-23.

7. Borges MC, Sesso ML, Roberti LR, de Menezes Oliveira MA, Nogueira RD, Geraldo-Martins VR, et al. Salivary antibody response to streptococci in preterm and fullterm children: a prospective study. Arch Oral Biol. 2015;60(1): 116-25.

8. Nogueira RD, Sesso ML, Borges MC, Mattos-Graner RO, Smith DJ, Ferriani VP. Salivary IgA antibody responses to Streptococcus mitis and Streptococcus mutans in preterm and fullterm newborn children. Arch Oral Biol. 2012;57(6):647-53.

9. Boix-Amorós A, Collado MC, Mira A. Relationship between milk microbiota, bacterial load, macronutrients, and human cells during lactation. Front Microbiol. 2016;7:492.

10. Fitzstevens JL, Smith KC, Hagadorn Jl, Caimano MJ, Matson AP, Brownell EA Systematic review of the human milk microbiota. Nutr Clin Pract. 2017; 32(3):354-64. Review.

11. Favier CF, Vaughan EE, De Vos WM, Akkermans AD. Molecular monitoring of succession of bacterial communities in human neonates. Appl Environ Microbiol. 2002;68(1):219-26.

12. Goldsmith F, O'Sullivan A, Smilowitz JT, Freeman SL. Lactation and intestinal microbiota: how early diet shapes the infant gut. J Mammary Gland Biol Neoplasia. 2015;20(3-4):149-58. Review.

13. Jeurink PV, van Bergenhenegouwen J, Jiménez E, Knippels LM, Fernández L, Garssen J, et al. Human milk: a source of more life than we imagine. Benef Microbes. 2013;4(1):17-30. Review.

14. van Herwijnen MJ, Zonneveld MI, Goerdayal S, Nolte-'t Hoen EN, Garssen J, Stahl B, et al. Comprehensive proteomic analysis of human milk-derived extracellular vesicles unveils a novel functional proteome distinct from other milk components. Mol Cell Proteomics. 2016;15(11):3412-23. 
15. Victora CG, Bahl R, Barros AJ, França GV, Horton S, Krasevec J, Murch S, Sankar MJ, Walker N, Rollins NC; Lancet Breastfeeding Series Group. Breastfeeding in the 21st century: epidemiology, mechanisms, and lifelong effect. Lancet. 2016;387(10017):475-90. Review.

16. Wong PD, Birken CS, Parkin PC, Venu I, Chen Y, Schroth RJ, Maguire JL; TARGet Kids Collaboration. Total breast-feeding duration and dental caries in healthy urban children. Acad Pediatr. 2017;17(3):310-5.

17. Tham R, Bowatte G, Dharmage SC, Tan DJ, Lau MX, Dai X, et al. Breastfeeding and the risk of dental caries: a systematic review and meta-analysis. Acta Paediatr. 2015;104(467):62-84. Review.

18. Bertoldo BB, Silva CB, Rodrigues DB, Geraldo-Martins VR, Ferriani VP, Nogueira RD. Comparisons of IgA response in saliva and colostrum against oral streptococci species. Braz Oral Res. 2017;31:e39.

19. Petrechen LN, Zago FH, Sesso ML, Bertoldo BB, Silva CB, Azevedo KP, et al. Levels and complexity of IgA antibody against oral bacteria in samples of human colostrum. Immunobiology. 2015;220(1):142-6.

20. Chen Z, Saxena D, Caufield PW, Ge Y, Wang M, Li Y. Development of speciesspecific primers for detection of Streptococcus mutans in mixed bacterial samples. FEMS Microbiol Lett. 2007;272(2):154-62.

21. Penders J, Thijs C, Vink C, Stelma FF, Snijders B, Kummeling I, et al. Factors influencing the composition of the intestinal microbiota in early infancy. Pediatrics. 2006;118(2):511-21.

22. Hunt KM, Foster JA, Forney LJ, Schütte UM, Beck DL, Abdo Z, et al. Characterization of the diversity and temporal stability of bacterial communities in human milk. PLoS One. 2011;6(6):e21313.
23. Jost $T$, Lacroix $C$, Braegger $C$, Chassard $C$. Impact of human milk bacteria and oligosaccharides on neonatal gut microbiota establishment and gut health. Nutr Rev. 2015;73(7):426-37. Review.

24. Ramsay DT, Hartmann PE. Milk removal from the breast. Breastfeed Rev. 2005;13(1):5-7.

25. Bik EM, Long CD, Armitage GC, Loomer P, Emerson J, Mongodin EF, et al Bacterial diversity in the oral cavity of 10 healthy individuals. ISME J. 2010;4(8):962-74.

26. Kong HH, Segre JA. Skin microbiome: looking back to move forward. J Invest Dermatol. 2012;132(3 Pt 2):933-9. Review.

27. Jost $T$, Lacroix C, Braegger CP, Rochat F, Chassard C. Vertical mother-neonate transfer of maternal gut bacteria via breastfeeding. Environ Microbiol. 2014; 16(9):2891-904.

28. Martín-Sosa S, Martín MJ, Castro MD, Cabezas JA, Hueso P. Lactational changes in the fatty acid composition of human milk gangliosides. Lipids. 2004;39(2):111-6.

29. Parahitiyawa NB, Scully C, Leung WK, Yam WC, Jin LJ, Samaranayake LP. Exploring the oral bacterial flora: current status and future directions. Oral Dis. 2010;16(2):136-45. Review.

30. Kliman HJ. Comment on "the placenta harbors a unique microbiome". Sci Transl Med. 2014;6(254):2541e4.

31. Davenport ES, Williams CE, Sterne JA, Murad S, Sivapathasundram V, Curtis MA. Maternal periodontal disease and preterm low birthweight: case-control study. J Dent Res. 2002;81(5):313-8. 